\title{
DOLLAR DAMAGE AWARDS TO FOREIGN PLAINTIFFS: CONVERSION AND REVALUATION OF FOREIGN CURRENCIES*
}

AMERICAN courts ignore changes in the value of money damages from the time they accrue to the time of judgment. ${ }^{1}$ In cases where American plaintiffs incur losses in the relatively stable dollar, ${ }^{2}$ courts' failure to take account of fluctuations in the purchasing power of money ordinarily works little hardship. However, the world-wide monetary inflation of the past decade has wrought far greater havoc on most foreign currencies. ${ }^{3}$ Foreign plaintiffs seeking compensation in American courts may thus recover but a fraction of their real loss.

In attempts to measure recoveries to foreign plaintiffs, American courts have long wallowed in confusion. Because all damage awards rendered in

*Paris v. Central Chiclera, S. de R.L., 193 F.2d 960 (5th Cir. 1952).

1. "Obviously, in fact a dollar or a mark may have different values at different times but to the law that establishes it, it is always the same." Deutsche Bank Filiale Nurnberg v. Humphrey, 272 U.S. 517,519 (1926). "[I]t is impossible to say that lei, measured by lei, had declined in market value." Richard v. American Union Bank, 241 N.Y. 163, 167, 149 N.E. 338, 339 (1925). "In measuring kroner in kronen, no account can be taken of the purchasing power of the money, nor the fluctuation value in money of a different country." Moser v. Corn, 140 Misc. 417, 418, 249 N.Y. Supp. 606, 607 (Sup. Ct. 1931). See also Shaw, Savill, Albion \& Co., Ltd. v. The Fredericksburg, 189 F.2d 952, 957-8 and n.26 (2d Cir. 1951).

2. Since 1801, the wholesale price index in the United States (Jan. 1939=100) has fluctuated between 60.5 (1896) and 234.5 (1951). Since 1820, the consumers' price index (same base period) ranged between 36.2 (1849) and 180.6 (1951). Hcarings Bcfore Joint Committee on the Economic Report, 82d Cong., 1st Sess. 236-7 (1951); 38 FED. Ress. BuLL. 194-5 (1952). For a comparison of the stability of the dollar with 25 of the leading currencies of the world, 1938-51, see appendix, page $764 \mathrm{infra}$. See also note 3 infrd.

3. Of the 57 nations reporting to the International Monetary Fund or the Statistical Office of the United Nations, none has escaped inflation. From 1938 to December 1951, prices of wholesale goods, the goods which enter the channels of international trade, have increased from a minimum of 71 per cent in the case of Venezuela to a maximum af about 200 trillion per cent in the case of Greece. Price levels in most countries are from two to five times 1938 levels. 5 International Financtal Statistics No. 2 (1952) [hercinafter cited as Int. Fin. Stat.]; 6 Monthly Bulletin of Statistics No. 2, 107-13 (1952) [hereinafter cited as Mónti. Bull. Stat.].

The classic inflation is that of Germany in 1923. The dollar quotations rose from a pre-World War I parity of 4.21 marks to 7,589 marks by December, 1922. The rundway began on January 11, 1923. The quotation of the clollar rose swiftly to 353,412 marks in July; 4,600,000 in August; $150,000,000$ on September 18; 1,200,000,000 'on October 9; $4,200,000,000,000$ on November 23. Nussbaum, MONEY in THE LAw 199-202 (1950). Dwarfing even the 1923 German inflation was the printing press holiday in Hungary, $1945-46$, when prices skyrocketed to at least $1,000,000,000,000,000,000,000,000,000,000,000$ times pre-war levels. On August 1, 1946, the Hungarian government exchanged 400,000, $000,000,000,000,000,000,000,000,000$ pengö for the new forint. BANK of INTERNATIONAL SetTlements, 17th ANNuAl Report 28-9 (1946-47). 
American courts must be expressed in dollars, ${ }^{4}$ a date for converting foreign currency damages into dollars had to be found. The date of breach and the date of judgment have been the principal conversion dates used by American courts. 5 The breach date receives its chief application in the "New York rule" 6 which converts the foreign currency loss into dollars at the exchange rate prevailing at the time of tort or breach of contract. In the absence of controlling state decisions, ${ }^{7}$ federal courts, on the other hand, employ the breach date only for causes of action "arising" in the United States. 8 If the cause of action "arises" elsewhere, they generally adopt the judgment-date, converting the foreign currency loss at the exchange rate of that day. ${ }^{0}$

4. E.g., Shaw, Savill, Albion \& Co. v. The Fredericksburg, 189 F.2d 952, 954 (2d Cir. 1951). Compulsory judicial conversion of foreign currency claims into dollars has prevailed since the Monetary Act of 1792, 1 Srat. 250 (1792), 31 U.S.C. \$371 (1946) and similar state legislation of the same period. Nussb.us, MoNey in tri. LAw 574 n.42 (1950).

5. Support may be found for at least seven different dates for converting foreign currency damages into the money of the forum: the time of making the contract, the time of breach or tort, the time of rescission, the time of commencing the suit, the time of trial, the time of judgment, and the time of collection. Fraenkel. Forcign . Moneys in: Donestic Courts, 35 CoL. L. Rev. 360, 362 (1935). See also Drake, The Profor Rule in Fluctualing Exchanges, 28 MICH. L. Rev. 229 (1930) : Riflind, Money as a Dezice for Mcasurisy Value, 26 COL L. REv. 559 (1926) ; Gluck, The Rate of Exchange in the Lane of Damages, 22 Col. L. Rev. 217 (1922) ; Notes: 65 HaRv. L. Rev. \&87 (1952); 52 Col. L. REv. 141 (1952) ; 36 VA. L. REv. 215 (1950).

6. This rule disregards conflicts of laws distinctions. See, e.17.. Parker v. Hoppe, 257 N.Y. 333, 178 N.E. 550 (1931) (breach of contract made and perfurmable in Russia); Sokoloff v. National City Bank of N.Y., 250 N.Y. 69, 164 N.E. 745 (1928) (breach of contract made in U.S. but performable in Russia). See alss, Compania Engraw Commercial E. Ind. v. Schenley Dist Corp., 181 F.2d 876 (9th Cir. 1950) (applying California law). But see Mlatter of United Shellac Corp., 277 App. Div. 147, 152-3, 97 N.Y. S.2d 817, 822 (1st Dep't 1950) for dicta implying that New York may now follow the distinction of federal courts, resting determination of the conversion date on conflicts of laws distinctions. See note $S$ infra. See also Mand, The Legal Aspect of Mloney 287 (1938).

7. See note 14 infra.

8. E.g., Hicks v. Guinness, 269 U.S. 71 (1925) ; Sutherland v. Mayer, 271 U.S. 272 (1926). And see Shaw, Savill, Albion \& Co., Ltd. v. The Fredericlisburg, 159 F.2d 952, 955 (2d Cir. 1951), 65 HARv. L. REv. 887 (1952): "The rationale of these cases is that the claim which the breach immediately creates is one payable in the currency of the place where the breach occurs, since the law of that place governs the measure of the damages." Id. at 88S. Compare Nussbaux, MoNey iN THE LAw 367 n.31 (1950) (author "not clear" whether place of payment or applicable law is the distinctive criterion) ; MIA:as, LEGAL Aspecrs of MONEY 284 (1938): "The question how the conversion is to be effected if the place of payment is in another country than that to whose law the contract is subjest. which law governs the determination of the situs of the place of payment, and how the money of account is to be ascertained, hare not yet received a satisfactory answer. . .." The recent federal cases applying the judgment-date contribute little enlightenment. In the Paris case, discussed infra, locus of both payment and applicable law apparently were in Mexico. In Shaw, Savill, Albion \& Co., Ltd. v. The Fredericksburg, 189 F.2d 952 (2d Cir. 1951), where the judgment-date was also used, the tort occurred in British waters.

9. E.g., Shaw, Savill, Albion \& Co., Ltd. v. The Frederichsburg, 189 F.2d 952 (2d Cir. 1951). The leading case supporting the judgment-date rule is Deutsche Banls Filiale 
In Paris v. Central Chiclera, S. de R.L., ${ }^{10}$ the most recent case involving currency conversion dates, the judgment date prevailed. A Mexican seller of bubble gum suffered an 83,150 peso loss in December, 1947, when the Texas buyer repudiated a contract of sale. At the time the contract was breached, the Mexican peso cost 20.6 cents in the New York foreign exchange market. ${ }^{11}$ The trial court converted the damages into dollars at the exchange rate of 21.3 cents which it found prevailing on the date plaintiff brought suit. ${ }^{12}$ This award would have enabled plaintiff to buy more than 152,000 pesos on re-exchange at the time of judgment because in the interim Mexico had devalued the peso to 11.6 cents. ${ }^{13}$

The Fifth Circuit held that the trial court used the wrong conversion date. Finding that the contract was made and performable in Mexico, the majority followed the federal decisions and held that conversion should have been made at the exchange rate prevailing on the date of judgment. ${ }^{14}$ This reduced

Nurnberg v. Humphrey, 272 U.S. 517 (1926), a 5-4 decision wherein Justice Holmes, speaking for the majority, asserted: "[W]e are lending our courts to enforce an obligation (as we should put it, to pay damages) arising from German law alone and ought to enforce no greater obligation than exists by that law at the moment when the suit is brought." Id. at 520 . It is clear from the dissent by Justice Sutherland and later cases, e.g., Royal Ins. Co., Ltd. v. Compañia Transatlantica Española, 57 F.2d 288 (E.D. N.Y. 1932), that Justice Holmes intended that the rate of exchange at judgment, not at the time the suit was brought, should apply. For other cases supporting the judgment-date rule, see Nussbaum, MONEY in the Law 368 n.33 (1950).

10. 193 F.2d 960 (5th Cir. 1952).

11. 1 Int. Fin. Stat. No. 4, 90-91 (1948).

12. 193 F.2d 960,961 n.1. The trial court used the exchange rate of 4.70 pesos to the dollar or 21.3 cents per peso. Other sources indicate, however, that the peso was still being quoted at 20.6 cents on the New York cable transfer market when plaintiff brought suit in 1948. See, e.g., Horoth, Mexico Devalues the Peso, 82 MAg. WAll St. 531 (1948).

13. The exchange rate on May 1,1950, the date of the trial court's judgment, was 8.62 pesos per U.S. dollar, or 11.6 cents per peso. See Brief for Appellant, p. 4, Paris v. Central Chiclera, S. de R.L., 193 F.2d 960 (5th Cir. 1952). See also 193 F.2d 960, 963. Under the pressure of continuing inflation, the Mexican government ceased "pegging" the peso at the artificial 20.6 cents level on July 22, 1948. After 11 months without controls, during which time the peso dropped to a more realistic level, Mexico returned to stabilizing its exchange at the new rate of 11.6 cents on June 17, 1949. Horoth, Mcxico Devalucs the Peso, 82 Mag. Wall St. 531 (1948); 5 Int. Fin. Stat. No. 2, 76-7 (1952).

14. 193 F.2d 960, 962-3. In this case, both the place of contracting and the place of performance were in Mexico. Conflicts doctrine would, therefore, fully support the majority's position that the obligation was governed by Mexican law. Nussnaun, PunCiples of Private International Law 159-60 (1943). But the court may have overlooked controlling state law standing for breach-date conversion. Erie v. Tompkins, 304 U.S. 64 (1938) may now compel federal courts in diversity cases to follow state precedent. The Second Circuit, in recently applying judgment-date conversion in a maritime case, did not decide whether Erie would have forced it to follow New York law, standing for breach-date conversion, in other situations. Shaw, Savill, Albion \& Co. Ltd. v. The Fredericksburg, 189 F.2d 952, 956 (2d Cir. 1951). But the Ninth Circuit reversed a federal district court's application of judgment-date conversion in favor of breach-date probably prevailing in California. Compania Engraw Commercial E. Ind. v. Schenley Dist. Corp., 
plaintiff's damages from the dollar equivalent of about 152,000 pesos to that of 83,150 pesos. The dissenting judge felt that because defendant had repudiated the contract in Texas, the court apparently should have adopted breachdate conversion. ${ }^{15} \mathrm{He}$ further castigated the majority for allowing the defendant, by invoking the law's delay, to deprive the plaintiff of almost half his recovery. ${ }^{16}$

The court's holding ignores the decline in value of plaintiff's currency. From the time of breach in December, 1947, until mid-1951, when inflation was halted, the wholesale price index in Mexico City rose 67 percent. ${ }^{17}$ Judgment-date conversion thus reduced the purchasing power of plaintiff's peso damages by 40 per cent. Breach-date conversion, apparently advacated by the dissent, ${ }^{18}$ would have given him a 10 per cent windfall, since the peso's drop on the American money markets exceeded its decline in purchasing power. ${ }^{19}$

Compared to the effects of conversion at the date of judgment, breach-date conversion roughly compensates foreign plaintiffs for their actual losses. Since foreign currency damages are translated into the typically more stable dollar at the breach-date exchange rate, the foreign plaintiff is sheltered from subsequent foreign currency inflation. ${ }^{20}$ But exchange rates at the date plaintiff converts his dollar award into his own currency may not reflect relative purchasing

181 F.2d 876 (9th Cir. 1950). Texas apparently applied the breach-date rule in Butler v. Merchant, 27 S.W. 193 (Tex. Civ. App. 1S94), which has been cited as authority for Texas adherence to breach-date conversion. Sec Page $v$. Levenson, 281 Fed. 555, 557 (D. 1Id. 1922).

15. The majority "[m]odified and affirmed" the trial court's decision because it used the wrong conversion date. Id. at 963 . One judge "dissented." He may have wanted to uphold the trial court's use of the date of filing suit as the conversion date, $c f$. id. at 963 , 965, or adrocated breach-date conversion. Because of the dissent's reliance on the Supreme Court decision in Hicks v. Guinness, 269 U.S. 71 (1925), thought to stand for breach-date conversion, e.g., Note, 65 HARv. L. REx. SS7, SSS (1952); Shaw, Savill, Albion \& Co., Ltd. v. The Fredericksburg, 189 F.2d 952, 955 (2d Cir. 1951), citing 5 Willisros, Co::TRACrs 3929-30 (rev. ed.), the latter interpretation appears more likely.

16. 193 F.2d 960,963 .

17. 1 Int. Fin. Stat. No. 4, 90-91 (1948); 5 Int. Fin. St八t. No. 2, $76-7$ (1952).

18. See note 15 supra.

19. The wholesale price index in Mexico City rose from 243 in December, 1947, to 405 in 1951, an increase of 67 per cent. Appendix, page 764 infro. Plaintiff would, therefore, have had to recover about 139,0001951 pesos to restore the purchasing power of his December, 1947, damages. Conversion into dollars at the rate used by the trial court, however, would have enabled plaintiff to buy over 152,000 pesos, 10 per cent more than necessary for full redress.

20. This "shelter" however, may not work to the foreign plaintiff's advantage in the historically" rare situation where the dollar has depreciated relative to the foreign currency on the money market. Breach-date conversion may then give foreign currency plaintiffs less than judgment-date conversion. E.g., Page v. Levenson, 2S1 Fed. 555 (D. MId. 1922); Sulka \& Co. v. Brandt, 154 Mrisc. 534, 277 N.Y. Supp. 421 (Sup. Ct. 1935): "The mere circumstance that the fluctuation of exchange went against the plaintiff would not seem to justify a departure from this rule." 
power fluctuations ${ }^{21}$ subsequent to the court's breach-clate translation of foreign currency losses into dollars. To the extent that the exchange rate at the date when plaintiff converts his dollar award back to his foreign currency overvalues that currency, his recovery will be less than his real loss. The converse, of course, is equally true, as illustrated by the facts of the Paris case: foreign plaintiffs may reap windfalls through breach-date conversion when internal purchasing power decline of their currency is less than its exchange rate drop. ${ }^{22}$ Even if purchasing power parity existed, the breachdate doctrine contains a further flaw. The value of the dollar may not remain stable from the time of breach to the time of judgment. Fluctuations in American price levels demonstrate the inadequacy of the dollar for service as an index number. Whenever the value of the dollar decrenses between breach and judgment, breach-date conversion usually will not restore plaintiff's full purchasing power loss. ${ }^{23}$

Judgment-date conversion, while largely avoiding the flaws of its breachdate counterpart, creates difficulties of its own. True, it eliminates the unsettling factors of relative purchasing power fluctuations not accurately reflected in exchange rates or changes in the value of the dollar between breach and judgment. However, judgment-date conversion forces the foreign plaintiff to bear the full risk of fluctuations in his home currency between breach and judgment. If there is foreign currency inflation, which is usually the case, plaintiff's monetary recovery restores only a fraction of his actual loss. ${ }^{24}$

21. For judicial expressions of the illusion that rates of exchange are tied directly to relative purchasing powers, see, e.g., Liberty Nat. Bank of N.Y. v. Burr, 270 Fed. 251, 255 (E.D. Pa. 1921); Kantor v. Aristo Hosiery Co., 222 App. Div. 502, 504, 226 N.Y. Supp. 582, 584 (1st Dep't 1928), aff'd, 248 N.Y. 630, 162 N.E. 553 (1928). If the supply and demand of foreign exchange (and hence the rate) were determined solely by the interchange of goods and services without any trade barriers or shipping costs, this might be true. However, many other factors, independent of the relative purchasing power of two currencies tend to disrupt any such equilibrium. Besides tariffs and the cost of shipping, these factors include governmental exchange controls, tourist expenditures, international loans and security transactions, international gift payments both public and private, and reparations. Halm, Monetary Theory 221-8 (1946); Chandler, Economics of Monty AND BANking 364-5, 388-95 (1948). After recent devaluation of the British pound, for example, its internal purchasing power decline was apparently far exceeded by its exchange-rate drop. See Shaw, Savill, Aibion \& Co. v. The Fredericksburg, 189 F.2d 952, 957 n. 25 (2d Cir. 1951).

22. Breach-date conversion would have given plaintiff a 10 per cent windfall becausc the peso had depreciated more on the foreign exchange market than in internal purchasing power. See note 19 supra. See also Shaw, Savill, Albion \& Co. v. The Fredericksburg, 189 F.2d 952, 956-7 (2d Cir. 1951) for similar results by British pound conversion at at date prior to judgment.

23. As the purchasing power of the dollar declines, plaintiff's damage rccovery normally will buy correspondingly less purchasing power in his own currency. To the degree that the foreign currency is overvalued compared to the breach-date, plaintiff's purchasing power recovery will be further reduced. Conversely, undervaluation of the foreign currency will tend to benefit the plaintiff. See notes 21 and 22 supra.

24. See, e.g., the principal case, discussed supra. 
And if there is deflation, defendant may by prompt tender forestall any converse gain to the plaintiff. ${ }^{25}$

In order to free judgment-date conversion of its shortcomings and thereby compensate foreign plaintiffs for their real loss, three alternatives are open to American courts: (1) to revalue damages when foreign law governing the obligation grants such relief; (2) to apply a uniform law revaluing all foreign currency damages when substantial monetary fluctuations have occurred; and (3) to assess damages which accurately reflect the cost to plaintiff of covering defendant's default in performance.

Revaluation by American courts whenever the foreign law governing the obligation so provides would be a substantial improvement over the present mechanistic judgment-date conversion. Most European countries which have been through the inflationary wringer in the past three decades have developed rules permitting revaluation by the court. ${ }^{20}$ But if the foreign country makes inadequate provision for revaluation, such "confiscatory" policy should not preclude independent revaluation by American courts. ${ }^{27}$

Thus American courts might adopt a uniform procedural rule adjusting foreign currency damages. The most adequate guide for such revaluation is the price index of plaintiff's country. 28 The general price level, as measured by the price index, varies inversely with the value of money. Wholesale and retail price indexes are prepared in all countries which trade with the United States and are readily available to both judge and litigants. ${ }^{.9}$ Choice of the proper index could be determined by the nature of plaintiff's purchasing power loss. Once the proper price index had been selected, actual revaluation would be a simple arithmetical computation.

American courts might also assess damages that accurately reflect the cost to plaintiff of defendant's default. The only method by which the foreign plaintiff could cover defendant's failure to perform or promptly compensate is by borrowing at interest rates prevailing in his home country. In times of inflation such interest rates tend to rise, reflecting foreign lenders' expecta-

25. Zimmermann v. Sutherland, 274 U.S. 253 (1927) (deposit of Austrian kronen with Austrian court after suit was brought held full discharge of obligation despite severe inflation from date of breach). See Sirie v. Godfrey, 196 App. Div. 529, 537, $18 S$ N.Y. Sugp. 52, 57 (1st Dep't 1921).

26. Among European countries which revalue claims or grant compensation for loss through monetary depreciation are Germany, Italy, Austria, Belgium, Switzerland, Poland, Rumania, and Hungary. Nussbaun, MFover IN THE LAw 180-88 (1950); Rashba, Debts in Collapsed Forcign Currescies, 54 YALE L.J. 1, 8-15 (1944).

27. See Rashba, stupra note 26 , at 34-5.

28. "Perhaps all civilized countries should have "commodity' (or 'price-indes' or 'purchasing power') currency." Shaw, Savill, Albion \& Co. v. The Fredericlisburg, 189 F.2d 952, 958 n. 26 (2d Cir. 1952).

29. Two excellent sources are International Financial Statistics and Mo:trily Bulletro of Statistics, monthly publications of the International Mfonetary Fund and the United Nations respectively: 
tions of declining purchasing power. ${ }^{30}$ Courts thus could add to plaintiff's damage award the interest cost of a hypothetical foreign currency loan between the dates of breach and judgment.

Once modified by revaluation, judgment-date conversion adequately compensates foreign plaintiffs for their purchasing power loss. Application of judgment-date conversion, moreover, should not turn on the elusive criteria determining where a cause of action "arose."31 Judgment-date conversion implemented by currency revaluation should be employed whenever suit is brought by a foreign plaintiff for damages sustained in a sharply inflated currency. And if inflation of the American dollar continues unchecked, revaltiation of American plaintiffs' dollar damage awards might become equally essential.

\begin{tabular}{|c|c|c|c|c|c|c|c|c|}
\hline \multicolumn{9}{|c|}{ APPEN } \\
\hline & \multicolumn{2}{|c|}{$\begin{array}{l}\text { Wholesale } \\
\text { Price Index } \\
1938=100\end{array}$} & \multicolumn{2}{|c|}{$\begin{array}{l}\text { Retall } \\
\text { Price Index } \\
1038=100\end{array}$} & \multicolumn{4}{|c|}{$\begin{array}{l}\text { Rate of Exchango } \\
\text { Cents per Unit Forolgn Curronoy } \\
\text { Averago N.X. Cablo Trunsfer rato }\end{array}$} \\
\hline & $\begin{array}{l}\text { Dec. } \\
1947\end{array}$ & $\begin{array}{l}\text { Dec. } \\
105 i\end{array}$ & $\begin{array}{l}\text { Dec. } \\
1947\end{array}$ & Dec. & & 1038 & $\begin{array}{l}\text { Doo. } \\
1047\end{array}$ & $\begin{array}{c}\mathrm{Dag} \\
105 \mathrm{i}\end{array}$ \\
\hline $\begin{array}{l}\text { nited States } \\
\text { anezuela } \\
\text { vitzerland } \\
\text { nadaa } \\
\text { ow Zealand } \\
\text { nion S. Africa } \\
\text { orway } \\
\text { ortugal } \\
\text { veden } \\
\text { ustralia } \\
\text { nited Kingdom } \\
\text { anmark } \\
\text { therlands } \\
\text { exico } \\
\text { dia } \\
\text { lgium } \\
\text { urkey } \\
\text { azil } \\
\text { jaln } \\
\text { ru } \\
\text { nland } \\
\text { rrmany } \\
\text { ance } \\
\text { aly } \\
\text { pan } \\
\text { eece (d) }\end{array}$ & $\begin{array}{r}208 \\
165 \\
218 \\
183 \\
175 \\
170 \\
179 \\
234 \\
186 \\
159 \\
201 \\
216 \\
270 \\
243 \\
314 \\
374 \\
\mathbf{3 5 1} \\
\mathbf{4 5 1} \\
341 \\
354 \\
360 \\
891 \\
1850 a \\
1217 \\
5525 \\
6360 \\
22000\end{array}$ & $\begin{array}{l}225 \\
171 \\
228 \\
232 \\
241 * \\
249 \\
271 \\
278 \\
287 \\
283 \\
329 \\
354 \\
403 \\
405 \\
454 \\
473 \\
505 \\
570 \\
789 \\
7440 \\
1770 \\
2450 \\
2030 \\
5810 \\
26800 \\
38500\end{array}$ & $\begin{array}{r}166 \\
182 \\
163 \\
143 \\
129 \\
140 \\
158 \\
208 \\
149 \\
138 \\
165 \\
164 \\
200 \\
309 \\
269 \\
346 \\
341 \\
330 \\
289 \\
308 \\
727 \\
1250 \\
1390 \\
4920 \\
21570 \\
21570\end{array}$ & $\begin{array}{l}187 \\
200 \\
172 \\
187 \\
174 \\
178 \\
202 \\
200 * \\
193 \\
220 \mathrm{~b} \\
207 \\
203 \\
262 * \\
438 \\
314 \\
396 \\
352 c \\
504 * \\
377 \\
480 \mathrm{c} \\
1050 \\
1710 \\
2063 \\
5420 \\
18100 * \\
35200\end{array}$ & $\begin{array}{l}\text { dollar } \\
\text { bollvar } \\
\text { franc } \\
\text { dollar } \\
\text { pound } \\
\text { pound } \\
\text { krone } \\
\text { nscudo } \\
\text { krona } \\
\text { pound } \\
\text { pound } \\
\text { krone } \\
\text { fullder } \\
\text { peso } \\
\text { rupeo } \\
\text { franc } \\
\text { pound } \\
\text { cruzelro } \\
\text { peseta } \\
\text { sol } \\
\text { markka } \\
\text { D.mark } \\
\text { franc } \\
\text { lira } \\
\text { yen } \\
\text { drachma }\end{array}$ & $\begin{array}{r}31.10 \\
22.87 \\
90.49 \\
392.35 \\
484.10 \\
24.67 \\
4.427 \\
25.20 \\
389.55 \\
488.04 \\
21.82 \\
55.01 \\
22.12 \\
30.60 \\
3.370 \\
80.11 \\
5.844 \\
5.000 \\
20.00 \\
2.157 \\
401.00 \\
2.878 \\
5.218 \\
28.45 \\
.006\end{array}$ & $\begin{array}{c}20.85 \\
23.30 \\
48.30 \\
322.80 \\
409.13 \\
20.10 \\
4.000 \\
27.83 \\
321.21 \\
403.13 \\
20.86 \\
37.70 \\
20.68 \\
80.18 \\
2.270 \\
36.34 \\
5.441 \\
0.132 \\
8.11 \\
.735 \\
\ldots .8408 \\
.8408 \\
.1058 \\
. .024\end{array}$ & 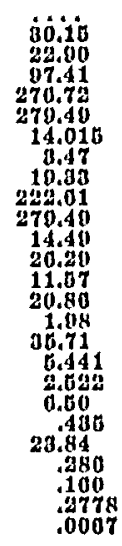 \\
\hline \multicolumn{9}{|c|}{ 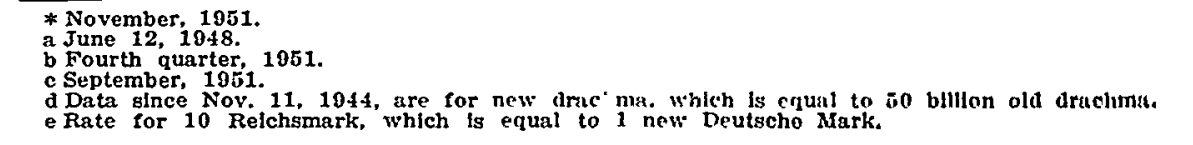 } \\
\hline \multicolumn{9}{|c|}{ 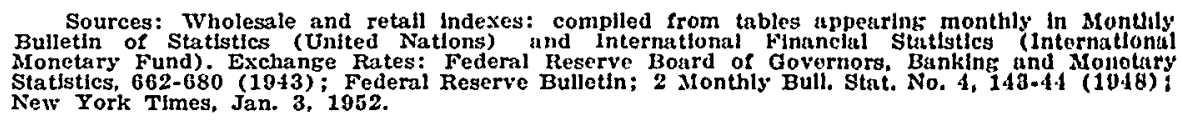 } \\
\hline
\end{tabular}

30. Foreseeing a price rise of $10 \%$ per anuum, a lender would have to charge $15 \% / \mathrm{s} \%$ interest to recoup his original purchasing power and earn a $5 \%$ return thereon. In actual practice, however, interest rates lag behind inflation and deflation. See FisHer: RATE of Interest 268-88 (1907) ; Purchasing Power of Money 56-8 (1931).

During the Mexican inflation, 1947-51, bank discount rates on short-term commercial paper rose to a high of 10.97 per cent. 5 Int. Fin. Stat. No. 2, 76-7 (1952). The customary lending rates in Germany from Nov. 15 to Nov. 30,1923, the closing days of that country's inflationary spiral, were 10 per cent daily. Nussbaum, MONEY iN THE LAW 165 n. 42 (1950).

31. See note 8 stpra. 